\title{
READING COMPETENCY AND METACOGNITIVE KNOWLEDGE IN PRIMARY SCHOOL CHILDREN: AN EXPLORATIVE SURVEY
}

\author{
Antonella Valenti, Lorena Montesano, Sonia Sapia, Pamela Iazzolino, \\ \& Orlando De Pietro \\ Department of Humanities, University of Calabria (Italy)
}

\begin{abstract}
Reading comprehension is a process of interaction between the characteristics of the text, the reader and the reading context. In a reader, numerous cognitive processes interactively contribute to comprehension. It is recognized as an important skill, is the basis of the more general study skills, on which depends largely, the educational and academic future of each student. Since learning from longer texts causes great difficulties for many students summarizing is one of the key strategies for good reading comprehension. Summarizing is one of the reading strategies that enables students to more deeply understand the text and it is an indicator of understanding at the same time. Based on these considerations, the ability to synthesise was evaluated in a group of pupils, aged 8 to 9 years, with typical development. Furthermore, the comprehension skills of the text were measured, with reference to the ability of semantic and lexical inference, to vocabulary skills and to metacognitive skills, in order to identify the relations between summarizing and students' general reading competency and metacognitive knowledge about reading.
\end{abstract}

Keywords: Text comprehension, primary school, summarizing, metacognitive knowledge.

\section{Introduction}

The current society, ever more globalized and characterized by a continuous production of information and the sharing of knowledge, it requires changes not only in the socio-productive sector but also and above all in the educational-training sector. It is clear how people are continually called to update their cultural profile and to acquire, as required by the European Framework of Reference for 2007 of the European Union (EC, 2009), communicative and methodological skills, useful to make appropriated the processes of learning to the needs of today's complex and liquid society (Bauman, 2011). The European Council (EU 2000, 2020, 2030) also stressed the central role of education for the development of member Countries and the strategic importance of the progressive and continuous improvement of intellectual capital.

It requires, therefore, to put in place a lifelong learning, as a strategy for the development of knowledge, personal development and social integration of individuals. It is possible if people develop skills in reading and understanding texts as processes aimed at grasping the meaning of the text and the construction of knowledge. The literature demonstrates how the comprehension competence of the text is part of the basic skills, crucial for the development of other skills (Oakhill \& Yuill, 19963; van den Broek \& Espin, 2012), and how to summarize, then synthesize, a text is a meaningful strategy for a good understanding of the text (Pečjak \& Pirc, 2018). Furthermore, low reading and comprehension skills have negative consequences for each student's academic future (Cain \& Oakhill, 2006).

The competence of reading, understanding and synthesis (summarize), therefore, must take shape from the first years of schooling as it is not only one of the conditions for dealing with everyday life, but it is also essential to succeed in the training, study and future professional life. Internationally, the OECD-PISA, since the first edition (1999), has paid particular attention to the assessment of this competence. Reading literacy is defined, in the Program, as the "ability to understand and use written texts, reflect on them and engage in their reading in order to achieve goals, to develop their own knowledge and potential and to be an active part of society". It is clear from this definition that the cognitive dimensions of the reading processes and the metacognitive ones, typical of the "levels of awareness and intentionality of one's strategies of thought" are added "that relating to the commitment invested by the subject in the action of reading" (Grange et al. 2009, p. 149). It is essential to evaluate whether the students possess this competence, as learning from long texts causes great difficulty for many students. Summarizing is a reading strategy that allows students to understand the text more deeply and, at the same time, is an indicator of understanding.

\section{Design}

To achieve the objectives of the survey, a battery of tests was administered to evaluate the ability to understand text and vocabulary in pupils aged 8 to 9 attending the fourth grade of primary school. 
The 5 classes involved in the survey were identified in two schools, located in two different geographical areas of Calabria, southern Italy region.

\section{Objectives}

The study intends to evaluate the ability to synthesize, by administering to a sample of pupils a summary test (Menichetti, 2018). Furthermore, in order to identify the relationships between the summary and the reading competence and metacognitive knowledge of the students, the comprehension skills of the text were measured, with reference to the capacity of semantic inference, vocabulary skills and metacognitive skills.

\section{Methods}

\subsection{Participants}

The sample of our research consists of 104 children attending the fourth grade of primary school, aged between 8 and 9 years, 56 females and 48 males. Students with a specific learning disability and with a cognitive disability certification were excluded from the sample, according to the Italian law $104 / 92$.

\subsection{Material}

The tools used are the following:

Verbal Meaning Test (PMA Battery, Thurstone \& Thurstone, 1965). The test was modified specifically for this research, including items of greater difficulty. The test consists of 30 items and allows to obtain a measure of the child's vocabulary. The child is asked to identify the word with the same meaning as the target word, among four alternative answers.

Inference test. In order to evaluate the inference skills, the story "Gimmy", of the Battery to deepen the difficulties in comprehension of the text was given (Tressoldi \& Zamperlin, 2007). The child is asked to read and answer 10 multiple-choice questions, which require to obtain inferential information from the reading of the piece.

Metacognitive questionnaire. For the metacognitive component, the questionnaire developed by the SApIE group (Society for Learning and Education informed by Evidence) was used. The questionnaire allows to investigate the awareness about the aims of the task, the knowledge of strategies to improve understanding, control during comprehension and sensitivity to the text.

Summarizing Test. To evaluate this competence the Summarizing Test version ST-A was administered (Menichetti, 2018). It is a tool that aims to assess the child's ability to recognize a good synthesis of a narrative text. The test consists of four texts, for each piece the child must read the text alone, in silence, and then answer a series of multiple-choice questions, in which the pupil must select from the proposals formulated, those that appear the most appropriate: each question presents six answer alternatives, all with a degree of acceptability, and asks the child to mark the three which, more than others, are suitable to represent in a synthetic way the piece read.

\subsection{Procedure}

The tests were given collectively in the individual classes, during school hours. The tests were provided one at a time and preceded by a moment of detailed explanation of the instructions. The total time taken to complete the work in each class was approximately 60 minutes.

\section{Results}

Table 1 shows the descriptive statistics (average, standard deviation) of the research sample.

Table 1. Average and SD of the scores obtained from the sample.

\begin{tabular}{|l|c|c|c|c|}
\hline & $\begin{array}{c}\text { Vocabulary } \\
\text { test }\end{array}$ & $\begin{array}{c}\text { Total } \\
\text { answers } \\
\text { "Gimmy" }\end{array}$ & $\begin{array}{c}\text { Metacognitive } \\
\text { score }\end{array}$ & $\begin{array}{c}\text { Total score. } \\
\text { Summarizing } \\
\text { Test }\end{array}$ \\
\hline Average & 22,65 & 4,12 & 10,22 & 21,61 \\
\hline SD & 3,80 & 1,73 & 3,74 & 4,97 \\
\hline
\end{tabular}

To examine the relationship between the synthesis abilities and the variables listed above, given the asymmetric distribution of some indicators, non-parametric correlations were calculated ( $\rho$ (rho) of Spearman). Significant correlations $(\mathrm{p}<0.01)$ emerged between the synthesis abilities and the variables taken into consideration with scores between .50 to .20 . 


\section{Discussion and conclusions}

The results obtained confirm the data present in the literature which underline the importance of lexical abilities and the comprehension of the text in the success of the study (De Beni et al., 2003; Tressoldi \& Zamperlin, 2007; Mirandola et al., 2018). The study revealed significant correlations between the various variables involved ( $\rho$ (rho) of Spearman between .50 to. $20 ; p<0.01$ ).

In particular, as far as linguistic aspects are concerned, several studies have shown that bad readers have poor performance in language comprehension tasks (e.g. receptive vocabulary, inferences, listening comprehension) (Catts et al., 2006; Carretti et al., 2011).

The collected data underline the importance of starting, already from kindergarten, activities that promote understanding, given the important role of this competence in the success of the study. The survey topic presented will be further explored, with an expansion of the sample, in order to find confirmation of the data already in our possession through a representative sample of the national reality and overcome the limit linked to the population investigated through the exploratory survey, which currently involves only one region of Italy.

\section{References}

Bauman Z. (2011). Modernità liquida. Bari: Laterza

Cain, K. \& Oakhill, J. (2006). Profiles of children with specific reading comprehension difficulties, British Journal of Educational Psychology, 76(4), 683-696.

Carretti, B., De Beni, R., \& Cornoldi, C. (2011). Il disturbo di comprensione del testo. In C. Cornoldi (Ed.), Difficoltà e disturbi dell'apprendimento (pp. 143-162). Bologna: il Mulino.

Catts, H. W., Adlof, S. M., \& Weismer, S. E. (2006). Language deficits in poor comprehenders: A case for the simple view of reading. Journal of Speech. Language, and Hearing Research, 49 (2), $278-293$.

De Beni, R., Cornoldi, C., Carretti, B., \& Meneghetti, C. (2003). Nuova guida alla comprensione del testo (vol. 1) Introduzione teorica generale al programma: le prove criteriali livello $A$ e B. Trento: Erickson.

EC (2009). The European Qualifications Framework for Lifelong Learning (EQF). European Communities, 2008. https://ec.europa.eu/ploteus/sites/eac-eqf/files/broch_en.pdf (last visit 16/02/2019).

EU (2000). For a stronger and wider union. Agenda 2000 - Volume I - Communication. DOC/97/6. Strasbourg: Commission of the European Communities. http://europa.eu/rapid/press-release_DOC97-6_en.pdf (last visit 16/02/2019).

EU (2020). Teaching methods and materials. https://ec.europa.eu/info/education/teaching-methods-andmaterials_en. Brussels: Commission of the European Communities (last visit 16/02/2019).

EU (2030). Transforming our world: the 2030 Agenda for Sustainable Development. Brussels: Commission of the European Communities.

Grance, T., Onorati, M. G., Revelli, L., \& Floris, P. (2012). Le competenze dei quindicenni in PISA 2009. Roma: Armando.

https://sustainabledevelopment.un.org/post2015/transformingourworld (last visit 16/02/2019).

Menichetti, L. (2018). Valutare la capacità di riassumere. Il Summarizing Test, uno strumento per la scuola primaria. Journal of Educational, Cultural and Psychological Studies, 18, 269-398.

Mirandola, C, Ciriello, A., Gigli, M., \& Cornoldi, C. (2018). Metacognitive Monitoring of Text Comprehension: An Investigation on Postdictive Judgments in Typically Developing Children and Children with Reading Comprehension Difficulties. Frontiers in Psychology, 9, 1-9.

Oakhill, J., \& Yuill, N. (1996). Higher order factors in comprehension disability: Processes and remediation. In J. C. Cornoldi and J. Oakhill (Eds.), Reading Comprehension Difficulties. Processes and Intervention (pp. 69-92). Mahwah, New Jersey: Erlbaum.

OECD (1999), Measuring student knowledge and skills. A new framework for assessment, OECD, Paris, http://www.oecd.org/education/school/programmeforinternationalstudentassessmentpisa/33693997 .pdf (Last visit. 16/02/2019).

Pečjak, S., \& Pirc, T. (2018). Developing summarizing skills in 4th grade students: Intervention programme effects. International Electronic Journal of Elementary Education, 10(5), 571-581.

Thurstone, T.G., Thurstone, L.L. (1965). P.M.A. Primary Mental Abilities. Firenze: Organizzazioni Speciali.

Tressoldi, P., \& Zamperlin, C. (2007). La valutazione della comprensione del testo: proposta di una batteria di approfondimento. Psicologia Clinica dello Sviluppo, 11 (2), 271-290.

van den Broek, P., \& Espin, C. A. (2012). Connecting cognitive theory and assessment: Measuring individual differences in reading comprehension. School Psychology Review, 41(3), 315-325. 